\title{
内耳道内に限局する聴神経腫瘍 \\ (Ear Tumor) の診断と治療
}

坂 田英 治*

\section{I はじめに}

聴神経腫瘍は脳腫瘍のなかで Gliom, Meningiomに次いで多いものといわ机脳腫瘍全体 の約10\%前後を占めている。

従来この疾患の診断は「電話一本で可能であ る」といわれ比較的容易なものとされて来た。 初期のものは, しかし，「神経性難聴」あるい は「高血圧による耳鳴」その他種々雑多な診断 名のもとに見逃がされ，手術決定時のものは著 明な聴力障害, 顔面神経や三文神経症状をはじ めとして多少の脳幹や小脳症状がみられるもの が大部分であった。「診断が容易である」とされ ているものは, この時期ないしはそれ以降のも のである。そのため本来は良性腫瘍であり根治 されるべき筈のこの疾患は，その発生部位が脳 幹に隣接するということのため, 多くの手術 死, 顔面神経や運動の麻痺, あるいは失調症な どの後遺症や再発をひき起こして来た。また手 術をおこなっても腫瘍の全摘出が不可能の例も まれではなく, そのために, 術後の生存数は短 縮されることも知られている一方, 進行例では 死亡するものも少くない。

従って早期にお打る診断と早期における適切 な治療法の開発が当然必要となるのであるが, 従来，ややもす机ばその努力が不足していたよ らに思わ秃る。

しかし乍ら, 神経耳科学の発達に伴って, 聴 神経腫場が内耳道内に限局して存在するいわゆ る“ear tumor”の段階においても診断が可能

* 順天堂大学助教授 (耳鼻咽喉科学) 昭和 45 年 4 月 24 日講演
となり 12 2) 334)5)，正確な診断とより精細にし て根治的な手術方法が開発されすでに二，三の 経験がなされている677)8)9)10)。

われわれは，過去10年間余り，乙の疾患の早 期診断と治療に関して注目してきたが，I 期の みならず，0期においても診断が可能であり， このようなものは中頭蓋窩経由硬膜外手術によ ってほとんど後遺症を残すことなく全摘出しう ることを知った。

この論文では, 本疾患の早期診断の要点と治 療法を述べ，従来一般にいわれている常識的な 症例に扔ける検查成績と対比検討し，ご批判を 仰ぐのがその目的である。

\section{III症例ならびに検査方法}

著者が過去 12 年の間に扱った聴神経腫瘍例は 73例である。これらは全て手術ないしは剖検に よって診断を確認し, しかも, 腫瘍の進展状況 と臨床所見とを詳細に対比検討することができ たものである。

そのうち, 腫瘍が内耳道内に限局し, 中頭蓋 窩経由硬膜外手術によって摘出をおこなった， いわゆる “0 期”のもの 8 例である。この小論 においてはこれら 8 症例について検討をすすめ たい。

検査は, 従来よりおこなわれている一般神経 学的検索とともに精細な前庭・平衡機能検査を 主体とする1112)13)14)15)。

\section{III 内耳道内に限局する Ear Tumor ( 0}

期) の診断

聴神経腫瘍は多く第 8 脳神経の前庭神経に原 
発するといわれ，内耳道内に発生したものは， そこに限局する。Mayfield ${ }^{16)}$ のいういわゆる “ear tumor”でありこの時期にすでに色々の 耳科的症状を自覚し, 患者のほとんどは耳科医 を受診している。ある神経学者はかって「内科 医はしばしば脳腫瘍を誤診する。耳科医はなお 悪いことに腫瘍の存在すら全く念頭にない」と 述べているように, この段階で聴神経腫瘍が早 期に診断されることは先ずなかった。「神経性 難聴」や「耳管狭窄症」あるいは「メニエール 病」などの名のもとに姑息的治療に終止してい る。腫瘍がさらに進展してI期へ，やがて II 期 の “brain tumor”となりはじめて, 他科の医 師によって診断されるのが大多数であった。

この点, 本症は耳科医にとって浪も関係深 く, かつ責任の重い疾患のひとつであると言え よう。

われわれが検討した“0 期”の症例を中心に 乙, 他の I 期以下の症例のうち時間的症状経過 を追跡できたものを含めて早期診断の要点をま とめてタると，表1のようになる。

Chronologisch に注, 症例によって, 多少前 後することがあるのはもちろんである。しかし 一般に, 自覚症状として耳鳴や難聴の自覚注早 期のものとしてみとめられる。腫瘍が前庭神経 に原発するものであり乍ら蝸牛症状が先行する 理由は恐らく, 前庭平衡系にほ中枢の代償機能 が存在するのに反し, 聴覚系の障害は, 一側の 障害がそのまま自覚されることに因ると考光ら れる。この腫場注本来良性であり, 発育も緩徐 であるため, 前庭系の障害は代償が十分なされ る余裕があるのにたいして，隣接する蝸牛神経 の圧迫症状が先行するものであろう。

頭痛や頭重感は, 内耳深く入りこんでいる脳 膜刺激症状として理解されるし, 顔面神経症 状, とくに，その知覚症状が早期に現われるこ とは，この神経が腫瘍で充満され，内耳道のな かで圧迫されることを考光れば当然である。

小脳や脳幹障害においてみなれる垂直ないし は斜行性眼振が頭位变換検查でみられること
は, 純粋に末梢前庭系に腫瘍が存在するこの時 期の場合, 一見理解が困難である。乙れは，患 側迷路動脈の閉塞がひいてはとの幹をなす前下 小脳動脈の血流障害をひきおこし，側副血行の 発生を促し, やがて borrowing \& lending syndrome ${ }^{17)}$ によって脳底動脈や反対側前下小 脳動脈系の循環不全を招出することが一因をな すものかと推察される。しかし乍ら, 眼振が小 打性であるため垂直・回旋眼振を垂直ない儿斜 行性のものと誤って観察する可能性もなしとし ないので注意を要する。

レ線学的診断は必ずしも確かでないことはわ れわ机がばしば経験するところである。正常 者においても左右差のみられることは多い。し かし年ら、い市ゆる “median type”のものを 除くと，他の諸症状に一致する側で拡大がみら 机る場合, 確か儿重要な補助診断のひとつと言 うことができよう。

\section{A. 自覚的症状}
1. 耳鳴・難聴
2. 頭痛・頭重感
3. 顔面神経症状
舌前部異常感, 顔面不随意の運動, 顔のまが り, 他

\section{4. 平衡障害}

身体のふらつき, 立ちくらみ, メマイ, 他

B. 他覚的症状
1. 温度刺激反応の高度低下ない乙脱落
2. 舌前部 $2 / 3$ 味覚障害
3. 聴力障害
4. 健側向き水平性眼振, 斜行性ない乙垂直性 頭位变換眼振
5. 顔面神経 (不全) 麻瘦
6. X 線学的所見
7. 脳脊髄液蛋白増加

表 1 ：内耳道内に現局する聴神経腫瘍（ 0 期）の自 覚ならびに他覚的症状。 他覚的症状のうち $1 〜 4$ の全部を有するとき はまず本疾患が疑わ秃るが， $5 \sim 7$ の 3 項目 のうち 2 項目以上がこれ蝴るときは臨床 的に本疾患を決定し, 中頭蓋哃経由硬膜外手 術の適応之考学る。 
「死の定義」として数えられる諸症状が，そ れぞれ単独では決して「死」に特有のものでは ないように，聴神経腫瘍の診断についてわれわ れがあげた他覚的 7 pnints も単独では本疾患 に特有なものはない。例えば「温度刺激反応の 脱落」は突発難聴や神経炎, あるいは陳旧性の メニエール病を汇じめ, いろいろの末梢前庭疾 患において稀ならずみとめられる。

しかし乍ら, 温度反応の高度低下や脱落と聴 覚障害飞第 7 脳神経症状功加わり, さらに末梢 前庭疾患にはみられないような「異型な眼振」 が観察されるとこの疾患を念頭に浮かべなくて はならなくなる(4 条件)。乙れに加えて顔面の 運動症状や髄液蛋白の増加, またレ線学的に内 耳道拡大像がみられるに至ると, 最早臨床的に 本疾患はほぼ確診ということができる（3 項 目)。(表 1 参照)。

\section{IV その治療}

1958年 House と Kurze は tic douloureux に対するSpiller-Frazier手術に準じて側頭部に 11/2インチ 4 方の小さな開頭をおこない, 硬膜 外飞側頭葉而上し 錐体学露出し microscope でのぞき乍ら dental drill を用いて上浅錐体 神経の骨よりの出口を目標にすぐ後方の膝状神 経節，さらに顔面神経をたどって内耳道上壁を 削りとり，内耳道を開放する方法を発表した。 これが middle fossa extradural approach ${ }^{6)}$ といわれるもので, House はこの方法により 10例ほどの聴神経腫瘍の摘除を報告している。

著者らもをたこの方法に準じで手術をおこな いその第 1 例を 1967 年「脳と神経」誌上に発 表10)すると共に第27回日本脳神経外科学総会に おいては別の症例について映画により報告し批 判3)4)に供した。

このような聴神経腫瘍手術法の発表は House, Kurze らのすぐれた着想と努力によるも のであるが，本邦を中心とする最近の神経耳科 学の発達による診断学の向上1)418119) と，また つぎのことがらにも支えられている。それは operating microscope を用いる microsurgery
の発達, cutting burr, high speed dental drill など, 内耳道開放のための器械の導入で ある。

この middle fossa approach は硬膜外でお こなうので，手術による全身的影響がきわめて 少なく、われわれの行なった症例は, 全て, そ の翌日から歩行し，手術の翌朝から空腹を訴光 て給食を全て平らげる程であった。また腫瘍被 膜と密着している顔面神経を保存し, さらに迷 路の vital artery である前下小脳動脈㕝損傷 することがない。手術手技に習熟すると，蝸牛 神経を損なわずに残し，小脳や脳幹を圧排する こともなく，乙かも腫瘍を全摘出することがで きるので， 0 期のものにとっては最良の方法と いうことができる。

今後，早期診断法の向上により，このような 腫瘍を対象とする機会がらえてくると考元られ るが，“ear tumor”であるか，他の疾患であ るか疑わしい場合には，やはり手術侵襲の少な いこの術式をとるのが得策である。また頑固な 耳鳴の治療, 進行難治性のメニエール病の治療 に, 侵襲と危険の多い Dandy 手術や完全破壊 の望めないことがある迷路破壊術や超音波療法 にとって代わる可能性もないわけではない。

\section{$\mathrm{V}$ 参考症例}

N. I., 33 ๙, 会社員, 右利き。

主訴: 左耳鳴, 左より後頭部痛, 左難聴, 左方 へのふらつき。

現症: 約 1 年前より 1 力月に 1 回程度, 嘔気を 伴なう頭痛の発作があった。階段の昇降や乗物 の乗り降りのときフラフラすることがあった。 6 カ月来腕時計を耳にあてたとき難聴を自覚, その後間もなく左耳鳴自覚。最近, 舌先端部に ザラザラした感じがある。時々左眼瞼のあたり がピクピクすることがある。

検查成績: (1)舌左前 $2 / 3$ で甘味, 塩味に対して軽 度の味覚障害, (2)左聴力は急墜型の高調音障 害, (3)温度検査で左側は水水 $40 \mathrm{cc} て ゙$ 刺激しても 無反応，(4)左下頭位検査で右向き水平性頭位眼 振, 頭位变換検查で右向き斜行性ないしは水平 
a 聴 力 図

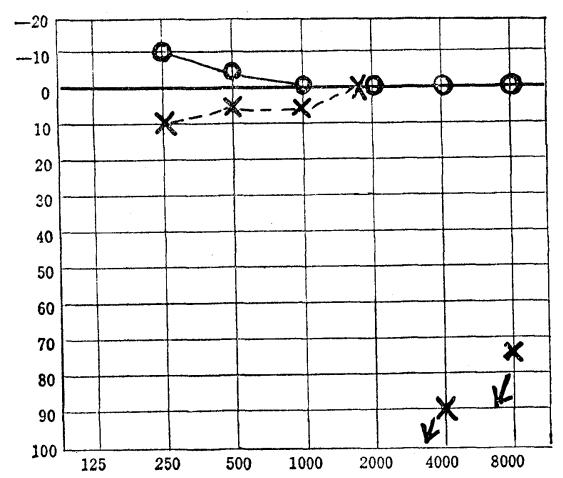

b 自発ならびに誘発眼振検査

1）自発 (狭義) ならびに注視眼振検查

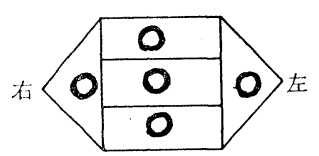

(坐位)

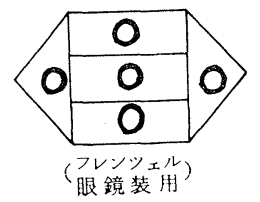

2）頭位検查

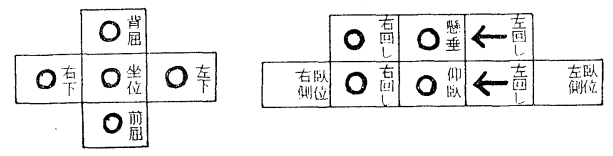

3）頭位变換検查

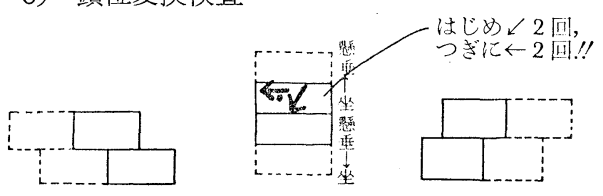

c OKP

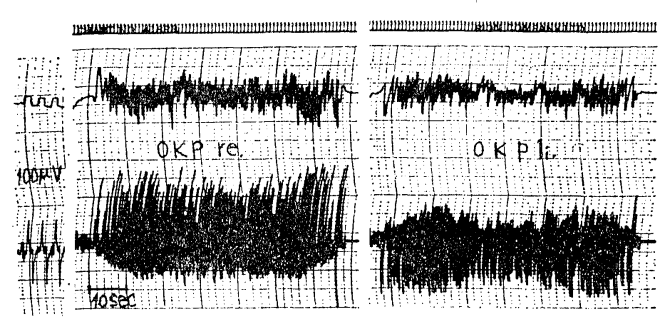

因 1：N.I., 33今，0期聴神経腫瘍例

聴神経腫济 (ear tumor) 彰断の 7 条件它ほぼ充足す る例。a）聴力は急墜型の高調音障害を示し b）健側 に向から水平ないしは斜行性の眼振がタられ 3) OKP は左右差が夕られ患側において眼振綏除相速度の上 昇不良と optokinetic fusion limit の低下がみられ る。
性眼振，(5)レ線検査では前後単純像, Stenvers 撮影でいら゙れも左内耳道がごく軽度に拡大，(6) 脳脊髄圧は $120 \mathrm{~mm} \mathrm{H}_{2} \mathrm{O}$ であるが，蛋白量は $42 \mathrm{mg} / \mathrm{dl}$ で正常上限を示していた。OKP テス トで軽度の左右差がみられたほかは，V，VI, IX脳神経症状をはじめ, 他の神経学的検査に異 常はみとめられていない（図 1)。

以上のような所見は, いら゙れも, 従来常識的 に考えられる I 〜 II 期の聴神経腫瘍に特異的な ものではない。すなわち, 通常久られる角膜反 射の減退または消失, 顔面神経麻痺, 脳幹小脳 症状, 髄液圧の㠵進などはみられず聴力障害も 定型的なものではない。しかし，温度反応の脱 落をはじめとして ear tumor 診断の 7 つの条 件のうち 6 条件をみたし, 総合的にも他の末梢 前庭疾患のうち最も疑わしいものと考察した。 聴力が保たれているので, House-Kurze 手術 の適応と考えて, middle fossa extradural approach により内耳道天井を開放して腫瘍を 摘出することにした。

手術は第 2 図 (a) のごとく側頭部に約 $4 \times$ $5 \mathrm{~cm}$ の大きさの開頭をおこない, 同時に腰椎 穿刺による脸春髄液の持続排除と mannitol の 点滴注入により脳を縮少させてから, 硬膜外に 側頭葉を挙上して，側頭骨錐体部の中頭蓋窝面 を十分に露出した。N. petrosus superficialis major が Ggl. geniculi を出るとすぐ骨の外に 出て走るので，乙机をとつの目標にして，こ の位置と走向とをたよりに, すぐ後方に位置す る膝状神経節に達した。 surgical microscope を用いて手術野を拡大して瞀き乍ら, cutting burr, diamond burr により顔面神経の走向に 沿って内耳道上壁をてい称いに削りとっていっ た。腫瘍は内耳道内にあり, 暗赤色で軟かく, 薄いが明膫な被膜をもっており，一見して聴神 経腫瘍であることがわかった。腫瘍注完全に内 耳道内に留って和り, 内耳道を拡大するに法至 っていなかった。大きさほ踠豆大で, 鋭匙で完 全に摘出することができた。腫瘍摘出後の軽度 の出血には gelfoam をあてて簡単に止血する 
a.

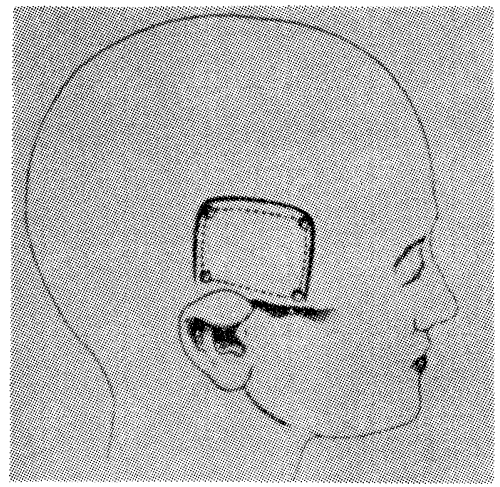

b.

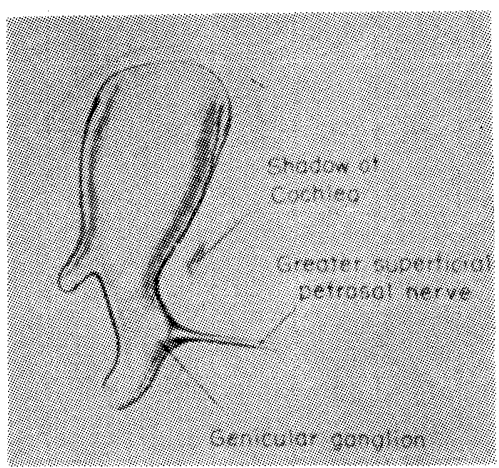

c.

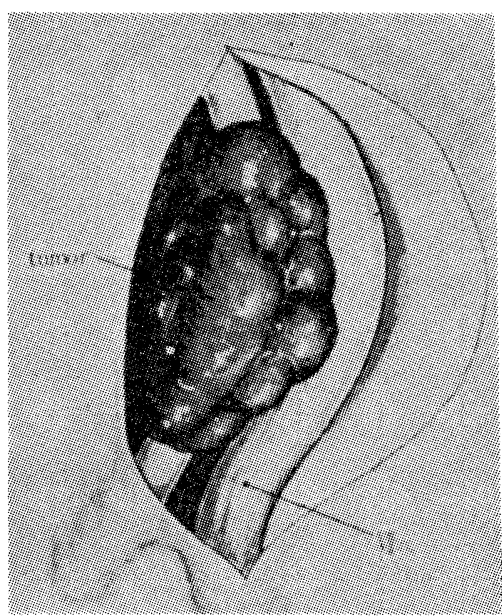

ことができた。開頭術とはいえ，すべて硬脳外 の操作のため, 術後経過はきわめて良好で，1 週間で退院した。摘出標本の病理組織学的所見 は典型的な聴神経鞘腫であった（図 2 )。 d.

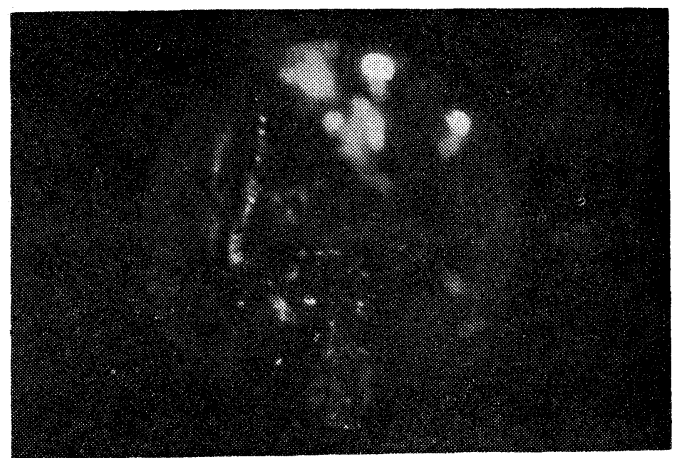

e.

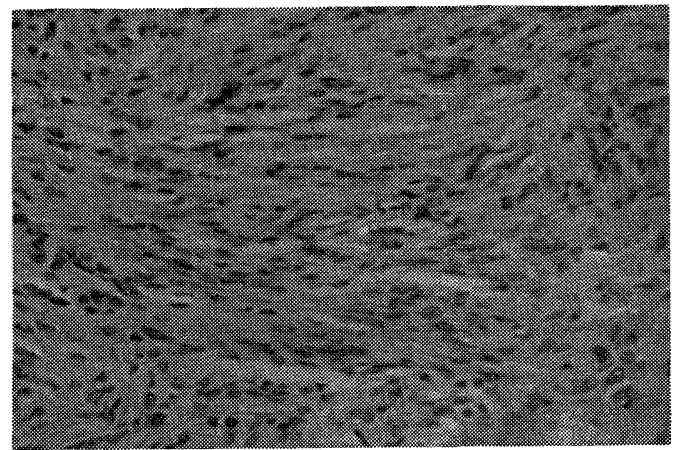

図 2：0期聴神経腫瘍例の手術経過

a) 側頭部に約 $4 \times 5 \mathrm{~cm}$ の大ささ開頭をおこなう。

b) 中頭窩面を露出乙 ggl. geniculi に達する。

c）踠豆大の腫瘍は完全に内耳道内に留ってあった。

d）この腫瘍を摘出した。

e) 病理組織学的には典型的な聴神経鞘腫であった。

\section{VI 聴神経腫瘍における神経学的症状の時間 的推移のまとめ}

われわれはこれまで，0期の聴神経腫瘍につ いて症例をあげて，その診断と治療について概 観した。

ここで Cushing の Chronologie による 1 期以下のものの症状についても簡単にふりかえ り，対比検討のよすがとしたい（表 2)。

\section{VII 聴神経腫瘍早期診断の 7 pnints ( 4 条 件 3 項目）と解説}

聴神経腫瘍は, 第 8 脳神経, とくに前庭神経 に原発し，いわゆる“median type”のものを 別にすると，普通初期には内耳道内に限局す 


\section{聴神経腫瘍症状の時間的推移}

\begin{tabular}{|c|c|c|c|c|}
\hline & 自・他覚的神経症伏 & 眼 & 振 & 腫瘍局在 \\
\hline 0 期 & 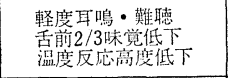 & 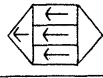 & \begin{tabular}{|l|}
$K$ \\
0 \\
\end{tabular} & $\begin{array}{l}\text { 内耳道内いわ叻引 } \\
\text { "Ear Tumor" }\end{array}$ \\
\hline I 期 & 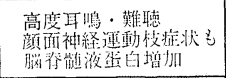 & $\langle\leftarrow$ & \begin{tabular}{|c|c|} 
Kan \\
0 \\
\end{tabular} & $\begin{array}{l}\text { 内山道孔外に } \\
\text { でてる }\end{array}$ \\
\hline II 期 & 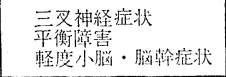 & $\sqrt[H E]{\leftarrow} \Rightarrow$ & \begin{tabular}{|l|l|}
$\mu$ \\
\end{tabular} & 訤政に及ぶ \\
\hline III期 & $\begin{array}{l}\text { 蕒明坴 } \mathrm{V}, \mathrm{VI}, \mathrm{VII}, \mathrm{VIII}, \mathrm{IX} \\
\mathrm{X} \text { 神経症状 }\end{array}$ & 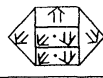 & $\frac{1.5}{\frac{1.5}{4.2} \rightarrow} \rightarrow$ & 小脳-脳翰を压迫 \\
\hline $\mathrm{IV}$ 期 & 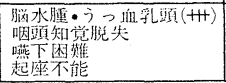 & $\sqrt{\frac{\pi}{0}} \Rightarrow$ & & 高度に圧迫 \\
\hline
\end{tabular}

表 2 : 聴神経腫瘍の神経学的諸症状の時間的推移の まとめ (坂田の分類)。0 0 期 (ear tumor) での診断は重要かつ可能であり, この時期に は中頭蓋筒経由手術によって全摘出が可能で ある。

る。この時期に診断をおこなうのが早期診断で あり，従来一般にいわれてきた I 期（腫瘍がす でに内耳道孔の外にタえるもの）のものの診断 は早期といいがたい。

神経耳科学の立場から, 次のような検査によ って十分診断が可能となった。「診断が可能と なった」というのは，新しい検查法が開発され たとか，また新しい診断技術が特に得られたと いうのではなく，生しろ，従来から存在する検 査法に従い乍ら，解剖学と生理学の基盤に立脚 した neurologischer Gedankengang をすす めることによって必然的に可能ならしめたとい うのが妥当であろう。敢てここにおいて特筆す ベき新しい知見を述べるならば，自発ならびに 誘発眼振所見に従った補助診断学的解釈であ り，また新しい技術とは初期腫瘍㫐䒨診例の中頭 蓋秱経由硬膜外手術の適用とこれら手術器械の 進歩であるら。疑診例のこのような手術による 診断確認がとりもな沶さず診断学の向上を促す

\section{こととなった。}

\section{1. 第 8 神経機能検査}

前庭神経に原発する聴神経腫瘍の患者が最も 早期に自覚する症状の多くは耳鳴や難聴であ る。理由はすでに述べたように, 前庭系には代 償機能が存在するのに反し，聴覚采にはとれが ないためであるうと考えられる。
聴覚検査はしたがって重要である。純音聴力 検査では感音性難聴を示すが，聴力障害の程度 と腫瘍の大きさとは必ずしも比例しない。われ われの症例で夕ると，内耳道内に限局するいゔ れもピース大前後の腫演 8 例において，4000お よび $8000 \mathrm{cps}$ の聴力損失が $30 \mathrm{~dB}$ 以内の值を示 すもの 4 例であるのに反し他の 4 例は全くの壟 である。このうち 1例は，250cps から 8000cps に至る全音域に扮いて測定不能である。因みに I 期のもの 8例についてみてもかなりマチマチ である。語音明瞭度は，しかし低下する。その う光歪語音明瞭度の不良が目立っている。純音 聴力検査で $4000 \mathrm{cps}$ と $8000 \mathrm{cps}$ の聴力損失が $30 \mathrm{~dB}$ 以内のものであった1例に秃いても患側 の歪語音明瞭度の低下がみられた。また 0 期や I 期のものでも健側の丕語音明瞭度も低下して いる(純音では正常聴力を示しながら)ことが あるの注興味深い事実である。補充現象は一般 に陰性である。

温度検查は最も重要な検査で，本疾患の診断 上大きな鍵穵握るものである。

普通スクリーニングとしては，アルコールな いしはェーテル它外耳道に滴下し，その気化熱 を利用して外耳道を冷し，外側半規管の反応性 をタるが，0 期のものでも無反応の例が少なく ない。水道水をそのまま用いたり，鼓膜穿孔の ある例では，予め冷蔵庫内で泠やしておいたり バノール水学滴下してもよい。

以上の検査によって反応がみられない場合， これで外側半規管機能の脱落とは言い得ない。 最終的にほ必ず氷水 ( $3{ }^{\circ} \mathrm{C}$ 前後のことが多い) 20ないし 100cc の注入によって検討し，これに よっても反応が全くみられないとき，外側半規 管機能は廃絶とみなしてよい。

ここで注意を要するのは，すでに健側に向う 自発眼振（狭義）の久られるばあいである。患 側に泠水を注入すると，もしその反応が現われ るとすれば，自発眼振の方向に発現するわけで ある。従って，誰が夕ても明らかな著るしい振 幅や頻度の増加がみられる場合は別として, 変 
化が僅かであったり，また無変化の場合であ る。たとえば多少頻度や振幅が増しても外側半 規管機能は実際には廃絶していることもある。 一般に自発眼振はごく簡単な刺激, 皮膚をつね って痛覚刺激を与えたり簡単な暗算の負荷や息 こらえによっても変化することが多い。外耳道 内に器物を挿入したり，冷水で皮膚を刺激する のであるから自発眼振がこれによって多少変化 しても(半規管が温度刺激にたいして反応して いないでも) 不思議はない。このような疑わし い場合，半規管内における対流の方向が逆にな るよう被検者の頭の検查位置を $180^{\circ}$ かえて検 査すべきである。被検者がほじめ坐位頭部後屈 $60^{\circ}$ で検查された場合ついで前屈させる。もし 反応があるとすれば，この操作によって自発眼 振は減弱し, さらには停止するか, 逆転するは ずである。眼振がとれでも全く変化しない場 合, 反応はほぼ廃絶と解釈する(図 3 )。

われわれの症例のうち(0 期ならびに I 期の 聴神経腫瘍計16例）温度反応が水水刺激によっ ても全くみら机ないもの12例, 数回前後の眼振 がみられたもの4例である。

自発眼振は必発で，健側に向かう微細な自発 眼振がみられることが多い。頭位変化の影響は 少ない。しかし，頭位变換検査をおこなうと既 に垂直性の要素を含导斜行性眼振肪みられる点 が他の温度反応低下を示し末梢前庭性疾患, た とえばメニエール病や神経炎, 内耳炎や突発難 聴の一部とやや異なるところである。われわれ は旧章においてこのメカニズムについてふれた 孞，迷路動脈の腫瘍による圧迫のための前下小 脳動脈への影響, さらには脳底動脈や反対側血 管系への影響が原因であろうと推察される。眼 振が小打性のため垂直回旋混合性のもの（末梢 性にも発現の可能性のある) を誤って観察して いる可能性についてもさきに述べた。健側の歪 語音明瞭度低下の事実と共に今後の研究課題で ある。

\section{2. 第 7 脳神経の検査}

顔面神経は内耳神経と共に内耳道内它走るの a .

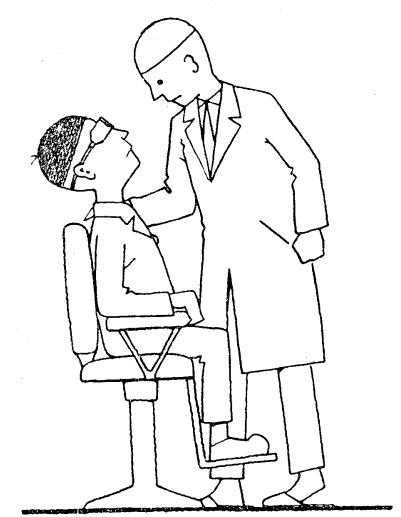

b.

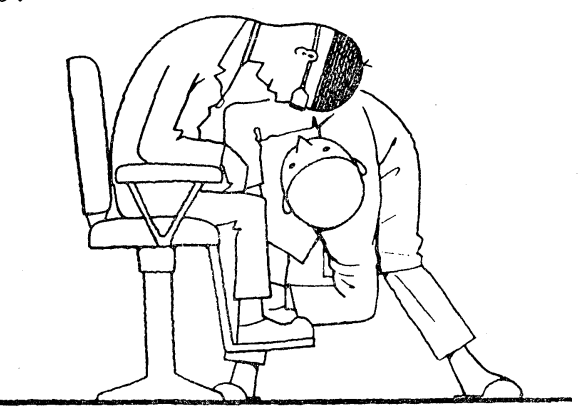

図: 3

a）健側に向かう自発眼振がすでに存在する例に患 側に冷水を注入して温度刺激反応を検査する場合 は慎重を要する。もし冷水注入によって多少眼振 の振幅や頻度が増加しても直ちに外側半規管機能 残存と決定できない場合がある。自発眼振は痛覚 負荷や暗算負荷などで変わることがあるからであ る。b) この場合被検者の頭の位置を $180^{\circ}$ 変えて 半規管内に現わ机る対流の方向定逆転させ，それ によって現われる自発眼振の停止や逆転現象の有 無などによって判定するべきである。この場合, 当然ながら, あらかじめ, この頭位での頭位眼振 を検査しておかねばならない。

で腫瘍の直接の圧迫や血流障害によって早期に その影響をうける。 0 期や I 期の腫瘍でもすで に運動症状があらわれ, 顔面神経の麻瘏してい る例も稀ではない。また額のシワが患側で少な かったり，鼻唇溝が浅かったり，笑うと口角が つれ，煩をらくらませて軽く拈すと患側口角か ら空気が洩れることもある。

しかし, 何よりも早期のものは舌前 $2 / 3$ の味覚 障害である。乙れは三叉神経の関与も十分念頭 
におかなくてはならないが，0 期や I 期の例で は三叉神経への影響は先づ考慮の外においてよ い。甘味, 辛味, 苦味などの検査をすると, い ゔれも早期に障害がある。

3. その他レ線学的診断法や髄液蛋白の増加 の有無を検查することは診断をより確かめる上 で重要である。これについては而章においても 述べているので詳述することは避けるが, 内耳 神経や顔面神経の機能検査成績に比べると多少 とも遅発する傾向がタられる。

\section{VIII 今後の課題}

今まで述べてきたように「診断学に関する進 歩」は決して特に新しいアイデアや診断的技術 によってなされたものではなく，あくまで考察 過程の整理整頓や手術方法の工夫や採用による ものである。

生化学的な方法によって前庭神経の感受性を 高めておき，その上で温度刺激をおこなって， 今まで夕とめられ得なかった微細な機能低下を もいち早く察知しょうという試みも一部企てら れているが，今後の研究に期待されるところが 大きい。

顔面神経領域の検査としてすでに研究者によ っては実施されている高速度写真による瞬目反 射の定量的測定法や， electric taste-taster 用いて味覚の定量的測定, さらには Schirmer test (Boberg-Ans 法の変法) で沪紙を用いて 涙液分泌の定量的測定をおこなう方法などいろ いろの試みがあるが，現在定説をみるに至って おらず，これまた今後の課題であろう。

0 期の聴神経腫瘍例に扔いてすでにみられる 斜行性ないし垂直性頭位変換眼振は, われわれ によってしばしば報告されているが，その発現 機構については脳幹部の血流障害が原因のひと つであろうと推察されている。確かにこのよう な眼振は, 他の末梢前庭性に起因する疾患, た とえばメニエール病や神経炎, あるいは内耳炎 などでは発現し得ないものであり，鑑別上重要 なものである。従って，この眼振の発現機構に
ついてのより精確な説明が今後なされることを 期待している。

レ線学的に pantopaque などを用いて小脸 橋角部の腫瘍陰影を映し出して腫瘍の大さ, 脳 幹との関係, さらに前下小脳動脈や内耳動脈な どとの関係をうつし出す方法も試みられている が，技術的問題や後遺症の問題に関してやや難 があるほか， 0 期の腫瘍の診断のためには現段 階では無力である。気脳法を用いてルーレット 断層撮影を掞こなう方法も知られているが，こ れにもほぼ同様の欠陥があげられる。

今後, 診断法の進歩により，ごく初期の腫瘍 を対象とする機会がるえ，耳科医が診断のみな らず治療にも関与すべき時代が近づいているこ とを信じて止まない。小さな “ear tumor”で あるか, あるいはメニエール病や神経炎の後遺 症であるか, その他いるいろの疾患にまたがる

“疑いのある症例” の発見という場合に，手術 侵襲の少ない中頭蓋简経由硬膜外手術は有用で 大いに利用されるべきであり，頑固な耳鳴や眩 量症例で聴力損失の高度な例では，乙れら耳鳴 やメマイの治療法として従来の手術方法にとっ てかわる日がくるのも夢ではない。

いゔれにせよ, 本疾患の早期診断は他の神経 疾患の場合之同様に, 綿密な神経学的検索が最 初にして，また最後の決を与えることになるこ とは言をまたない。

\section{IX むすび}

以上, 聴神経腫瘍の早期診断の問題を中心 に, 多少ともこまごまとした診断上の諸問題に ついて述べてきた。

末梢および中枢の前庭系に関する病態生理の 解明は昨今脚光をあびつつある「神経耳科学」 neurotology の中心課題である。聴神経腫瘍 は，その発生部位が特異で，末梢前庭系と中枢 前庭系の境界にあって, 前者, あるいは後者を 特異的におかす点，また，さきにのべたように 耳科医が比較的しばしば遭遇する脸腫瘳である 点, 神経耳科学を志す者にとっては重要な疾患 
であり, いわば好個の研究材料を提供してき た。

メニエール病が種々の内耳疾患の中心として あるように, 聴神経腫瘍は, 後迷路の中心的疾 患として，他の近縁疾患との鑑別の目やすとな ってきた。メニエール病と聴神経腫瘍の両疾患 の臨床に精通して, 確実な診断につとめること は，とりもなおさず，それらを，他より浮きた たせ，また，他の一つ一つをも明らかにする。

このような意味あいから，本論文では細目に わたって聴神経腫瘍診断に関する技術的検討を こころみたが，以上のような観点から諸賢のご 批判とご叱責をうれば幸いである。

(河村正三教授のご校閲を深謝する)

\section{$\mathrm{X}$ 主要文献}

1) Sakata, E., Tokumasu, K., u. Komatsuzaki A.: Spontan-und Provokationsnystagmus beim Acusticustumor. HNO (Berl.) $11: 310,1963$.

2）坂田英治：前庭平衡機能検查最近の進歩, 自発な らびに誘発眼振検査の診断的意議, 耳鼻咽喉科最 近の進歩, 275, 医歯薬出版, 東京, 1968.

3）坂田英治, 他 : 聴神経腫瘍の早期診断, 第26回日 本脳神経外科学会抄録集, 岐阜, 1967.

4）坂田英治, 内耳道内に限局する聴神経腫湯 ( 0 期) の診断と治療, 第27回日本脳神経外科学会抄録集 東京, 1968.

5）坂田英治：中枢性疾患ことに天幕下疾患における 眼振の診断的意義, 小脳橋角腫瘍を中心とする自 発眼振(広義)を中心に, 耳喉 $34: 735,1961$.

6) House,W.F. : Surgical Exposure of the Internal Auditory Canal and its Contents through the Middle Cranial Fossa. Laryngoscope. $71: 1363-1$ 385, 1961.

7) House, W.F : Middle Cranial Fossa Approach to the Petrous Pyramid ; report of 50 cases. Arch. Otolaryng. (Chicago) 78: 460-469, 1963.

8) House, W.F. : Transtemporal Bone Microsurgicl Removal of Acoustic Neurinoma. Arch. Otolaryng. (Chicogo) $80: 576-756,1964$.

9) Kurze, T.L. and Doyle, J. B. Jr. : Extradural intracranial (Middl Fossa) Approach to the
Internal Auditory Canal. J. Neurosurg. 19 : 1033-1037, 1962.

10）寺尾栄夫, 他: 聴神経腫瘍の Transtemporal Approach による手術, 脳と神経 19:779，1967.

11）切替一郎, 坂田英治: 自発ならびに誘発眼振の検 查法, 耳鼻咽喉科臨床検査法, 医学書院 179, 1965.

12）坂田英治, 他: 頭位変化時にあらわれる眼振（頭 位変化眼振) に関する研究一検査法の提案, 日耳 鼻 $64: 1402,1961$.

13) Suzuki, J. and Komatsuzaki, A. : Clinical Application of Optokinetic Nystagmus. Optokinetic pattern Test. Acta oto-laryng.(Stockh.) $54: 49,1992$.

14）坂田 英治, 五島一吉, 許 瑞光: Opto-Kinetic Pattern test (OKP test) の診断的意義に関する 検討, 日耳鼻 $69: 2034,1966$.

15）坂田英治, 他：メマイ・平衡障害における視性運 動性後眼振(OKAN)検査の診断的意義(印刷中).

16) Bradley, W.H. : An Appraisal of the Transtemporal Approach in Acoustic Neurinoma.

J. Neurosurg. $22:$ 402-403, 1965.

17）坂田英治, 他: 上小脳動脈障害の診断, メニエー ル病とその周辺第 2 報, 耳鼻臨床 $61 ： 690,1968$.

18）上田良穂, 他: 聴神経腫瘍の早期診断に関する 2 〜3 の考察, 耳喉 $40: 275,1968$.

19）吉本 裕 : 聴神経腫瘍の臨床的ならびに文献的考 察(その 2)一神経耳科学的検査所見について, 耳 喉 $40: 531,1968$.

20) Panse, R. : Ein Gliom des Akustikus. Arch. Ohrenheilk. 61 :251-255, 1904.

21) Quix F. : Ein Akustikustumor. Arch. Ohrenheilk. $84: 252-253,1911$.

22) Schmiegelw, E. : Beitrag zur translabyrinthãren Entfernung der Akustikustumoren. Z. Ohrenheilk. $83: 1-21,1915$.

23) Dandy, W. E. : Operation for Total Removal of Cerebellopontine Acoustic Tumors. Surg. Gynec. Obstet. $41: 129-418,1925$.

24) Rand, R. W. and Kurze, T. L. : Facial Nerve Preservation by Posterior Fossa Transmeatal Microdissection in Total Removal of Acoustic Tumours. J.Neurol. Neurosurg. Psychiat. 28 : 311-316, 1965. 